\title{
Vegetation and peat characteristics of restiad bogs on Chatham Island (Rekohu), New Zealand
}

\author{
BEVERLEY R. CLARKSON \\ LOUIS A. SCHIPPER \\ Landcare Research \\ Private Bag 3127 \\ Hamilton, New Zealand \\ Email: bev@landcareresearch.co.nz \\ BRUCE D. CLARKSON \\ Centre for Biodiversity and Ecology Research \\ Department of Biological Sciences \\ The University of Waikato \\ Private Bag 3105 \\ Hamilton, New Zealand
}

\begin{abstract}
Restiad bogs dominated by Sporadanthus traversii on Chatham Island, New Zealand, were sampled to correlate vegetation patterns and peat properties, and to compare with restiad systems dominated by Sporadanthus ferrugineus and Empodisma minus in the Waikato region, North Island, New Zealand. Classification and ordination resulted in five groups that reflected a disturbance gradient. The largest $S$. traversii group, which comprised plots from central, relatively intact bogs, had the lowest levels of total nitrogen (mean $1.20 \mathrm{mg}$ $\mathrm{cm}^{-3}$ ), total phosphorus (mean $0.057 \mathrm{mg} \mathrm{cm}^{-3}$ ), total potassium (mean $0.083 \mathrm{mg} \mathrm{cm}^{-3}$ ), and available phosphorus (mean $18.6 \mu \mathrm{g} \mathrm{cm}^{-3}$ ). Modification by drainage, stock, and fires resulted in a decline of $S$. traversii and an increase of Gleichenia dicarpa fern cover, together with elevated peat nutrient levels and higher bulk density. Compared with peat dominated by Sporadanthus ferrugineus or Empodisma minus in relatively unmodified Waikato restiad bogs, Chatham Island peat under $S$. traversii has significantly higher total potassium, total nitrogen, available phosphorus, bulk density, and von Post decomposition indices, and significantly lower $\mathrm{pH}$.
\end{abstract}

B03019; Online publication date 3 June 2004 Received 18 June 2003; accepted 1 October 2003
Sporadanthus traversii and Empodisma minus have similar ecological roles in restiad bog development, occupying a relatively wide nutrient range, and regenerating readily from seed after fire. Despite differences in root morphology, $S$. traversii and $E$. minus are the major peat formers in raised restiad bogs on Chatham Island and in Waikato, respectively, and could be regarded as ecological equivalents.

Keywords peat; bog; nutrients; disturbance gradient; Restionaceae; Waikato; Sporadanthus traversii; S. ferrugineus; Empodisma minus

\section{INTRODUCTION}

Bogs dominated by Restionaceae (restiad bogs) on a global scale are most extensively developed on mainland New Zealand (Campbell 1983) and Chatham Island (Wardle 1991). However, there are marked differences in restiad species dominance between the two regions. Empodisma minus is widespread and abundant on mainland New Zealand (also found in Australia) whereas it is absent from Chatham Island (de Lange et al. 1999a). Further, Sporadanthus ferrugineus is endemic to northern North Island (de Lange et al. 1999b) and dominates older (>4000 years) Waikato bogs (Clarkson et al. 2004), whereas Sporadanthus traversii is endemic to, and widespread on, Chatham Island (de Lange et al. 1999b).

Waikato restiad bogs have been the focus of recent research on bog development and functioning (Clarkson et al. 2004) but equivalent data from Chatham Island have not been available. Following the recent revision of Sporadanthus (de Lange et al. 1999b), which separated the taxa on mainland New Zealand and Chatham Island as distinct species, we were particularly interested in comparing the two systems. In addition, Chatham Island peatlands are much older. Peat accumulation began there in the interglacial period about 40 000-30 000 years ago (Mildenhall 1994; Campbell 1996), while Waikato 


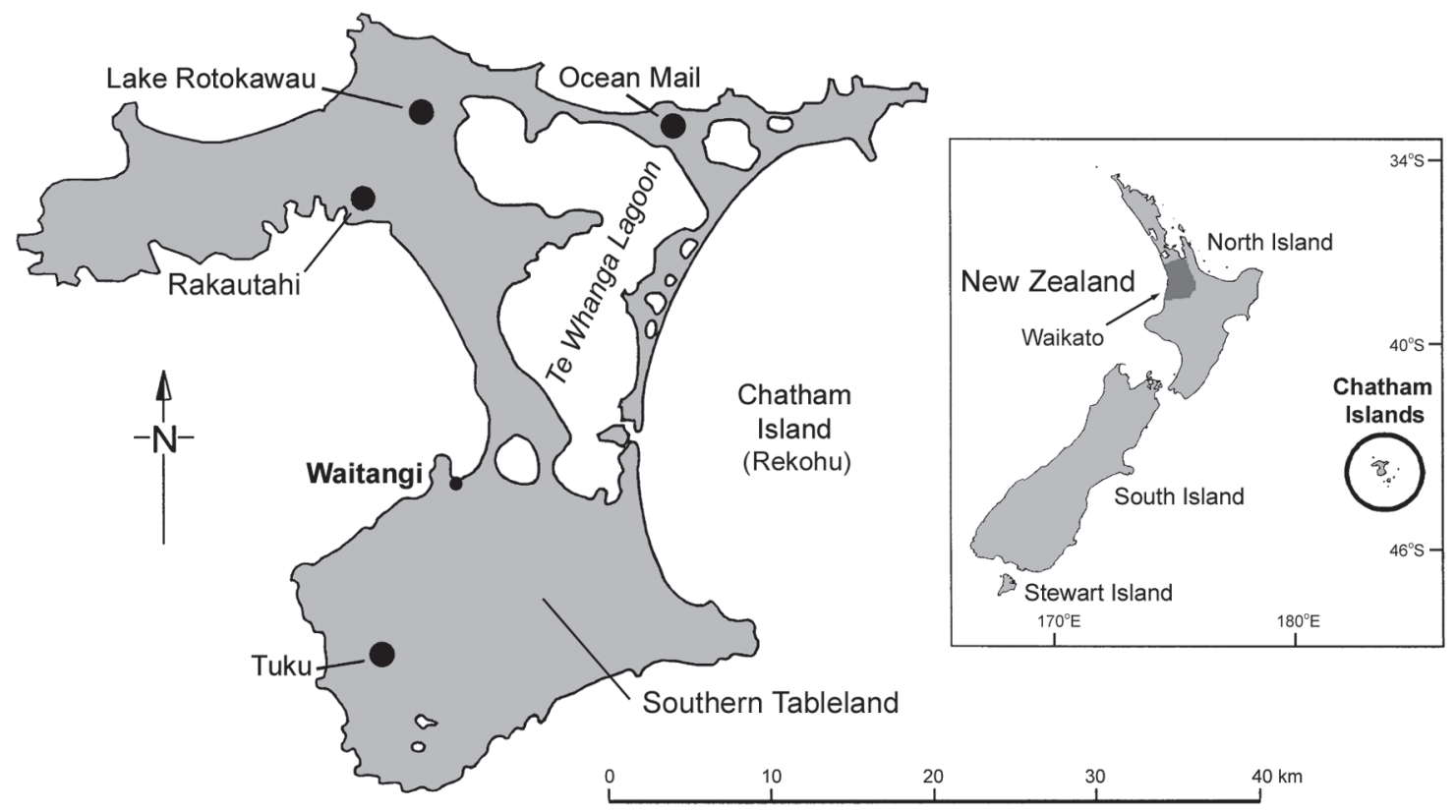

Fig. 1 Chatham Island showing sampling locations.

systems are post-glacial, ranging from a few hundred to c. 15000 years (Hogg et al. 1987; Newnham et al. 1995). Finally, although affected by humans, the Chatham peat systems are still relatively intact compared with the much-reduced Waikato peatlands, but share similar threats of fire, drainage, and stock damage.

We therefore conducted a plot-based survey of bogs dominated by S. traversii, measuring both vegetation and peat characteristics, to understand basic processes of peatland functioning. Specifically, our research goals were to:

1) correlate peat physical and chemical properties with vegetation patterns in Chatham Island restiad bogs; and

2) compare and contrast Chatham Island bogs dominated by $S$. traversii with Waikato systems dominated by $S$. ferrugineus and Empodisma minus.

\section{STUDY AREA}

\section{Background}

Chatham Island, c. 90000 ha in area, lies $870 \mathrm{~km}$ east of the New Zealand mainland at latitude $44^{\circ} \mathrm{S}$ within the New Zealand biogeographical area (Fig. 1 ). Its topography is mainly flat to gently rolling, with the lowland northern half dominated by a large lagoon and the southern half by a tableland averaging $260 \mathrm{~m}$ above sea level (a.s.1.). The highest point is Maungatere Hill, reaching $294 \mathrm{~m}$ a.s.l. in the centre of the Southern Tableland. Geologically the island is diverse, comprising sedimentary rocks, volcanics, and schists. Extensive areas are covered by peat, with $59 \%$ of the soils being peat or derived from peat (Wright 1959). Most of the peatlands are blanket peats, e.g., the Dracophyllum arboreumdominated peats on the Southern Tableland, but there are also many raised bogs, which typically occur in the middle of peat-filled basins (McGlone 2002). The raised bogs and many of the lowland blanket peats are dominated by Sporadanthus traversii, in association with Dracophyllum scoparium, Gleichenia dicarpa, and Olearia semidentata.

The island has a cool, damp, and windy climate (Wright 1959). Its first inhabitants, the Polynesian Moriori, knew it as Rekohu, Misty Skies, because of the mists that often enshroud the island for days at a time (Wills-Johnson 1996). Climatic extremes are moderated by the surrounding expanse of ocean, and no part of the land is more than $8 \mathrm{~km}$ from the 
sea. At Waitangi, the main settlement, the mean annual temperature is $11.3^{\circ} \mathrm{C}$ (July average $7.8^{\circ} \mathrm{C}$, January average $14.5^{\circ} \mathrm{C}$ ) with a low annual mean daily range $\left(5.4^{\circ} \mathrm{C}\right)$, very few air frosts (only one every 2 years), and low annual sunshine hours (1474) (Thompson 1983). Mean annual rainfall is low (895 $\mathrm{mm}$ at Waitangi; 715-1050 mm elsewhere on the island) with summer dry spells, but frequent cloud cover (averaging 74\%), moderately high humidity (mean relative humidity $84 \%$ ), and cool temperatures contribute to an environment conducive to peat accumulation (Wright 1959).

General accounts of vegetation types have been provided by Cockayne (1902), Wright (1959), Kelly (1971, 1978), Wardle et al. (1986), Given \& Williams (1984), Atkinson (1996), and Given (1996). In addition, Kelly (1983) assessed significant conservation sites, Walls \& Baird (1995, 1997) monitored vegetation recovery following fire, and Mildenhall (1994) and McGlone (2002) interpreted the vegetation history from palynological studies. Information on peat, including soil development processes and chemical analysis, has been published by MacPherson \& Hughson (1943), Blakemore (1958), and Wright (1959).

\section{Study sites}

Four peatlands were selected (based on Kelly (1983), an extensive reconnaissance by BRC \& BDC in 1996 , and 1996/97 colour aerial photographs of scale $1: 10000)$ to encompass the range of vegetation pattern, altitude, and modification represented in the restiad ecosystems (Fig. 1). These were Ocean Mail (10 $\mathrm{m}$ a.s.1.), Lake Rotokawau (40 $\mathrm{m}$ a.s.1.), Rakautahi (60 $\mathrm{m}$ a.s.1.) in the northern lowlands, and Tuku (240 m a.s.l.) on the Southern Tableland. They comprise various peat types from drier blanket bogs to wetter basins to raised bogs, and are dominated by Sporadanthus traversii.

\section{Ocean Mail}

Ocean Mail Scenic Reserve (830 ha) on the north coast comprises a raised bog in the east and a peat basin containing several peat lakes in the west (Kelly 1971). It was burnt in November 1994 (Walls \& Baird 1997), and at the time of sampling (February 2001) the raised bog was dominated by Sporadanthus traversii up to about $80 \mathrm{~cm}$ tall with common associates being Dracophyllum scoparium, Gleichenia dicarpa, and, locally, Olearia semidentata (Fig. 2). Apodasmia similis dominated the margins and was also abundant, together with $S$. traversii and Phormium tenax, around Lake
Kaimoumi, near the south-western margin of the peat dome (Fig. 3). The understorey was made up of a mixture of herbs, e.g., Pratia arenaria, Gentiana chathamica, sedges, e.g., Carex chathamica, and grasses, e.g., Poa chathamica.

\section{Lake Rotokawau}

This is mainly private land, although a small Conservation Area (administered by Department of Conservation) is included, and consists of a peat basin around Lake Rotokawau extending into a raised bog to the east. The vegetation (Fig. 4) is similar to Ocean Mail except it was taller (about $1 \mathrm{~m}$ tall), A. similis was not recorded, and non-vascular species (e.g., Sphagnum australe, Dicranum billardierei, Riccardia cochleata) were more prominent. Large areas near the bog margins and around Lake Rotokawau had been modified by cattle and drainage, having a high component of exotic herbs and grasses. In these areas $S$. traversii had been heavily browsed and localised patches of vegetation were dominated by $D$. scoparium or $G$. dicarpa. The vegetation condition in many parts of Lake Rotokawau had noticeably deteriorated and cattle damage was more evident than when the area was visited by BRC and BDC in 1996.

\section{Rakautahi}

Rakautahi is a large blanket bog on privately owned land, $5 \mathrm{~km}$ south of Lake Rotokawau, with Port Hutt Road forming its southern boundary. An extensive area was burnt in 1999, some 18 months before sampling (A. Baird pers. comm. 2001). It was still in the very early stages of recovering after the fire as much of the surface was bare peat with scattered low $(<20 \mathrm{~cm})$ vegetation of mainly Gleichenia dicarpa, Sporadanthus traversii, and Dracophyllum scoparium (Fig. 5). Several islands of vegetation (comprising $G$. dicarpa, $S$. traversii, and $D$. scoparium) up to $1 \mathrm{~m}$ tall had survived the fire and were prominent on the burnt landscape.

\section{Tuku}

Located on the Southern Tableland the sample site is a peat basin centred in Tuku Nature Reserve and extends north-eastward into adjacent privately owned land. Surrounded by blanket peats dominated by Dracophyllum arboreum forest, it was the least modified of the four peatlands sampled. In addition, an intensive control programme for introduced predators and browsing mammals is currently being undertaken within the reserve to protect populations of the rare sea bird, Chatham Island taiko 


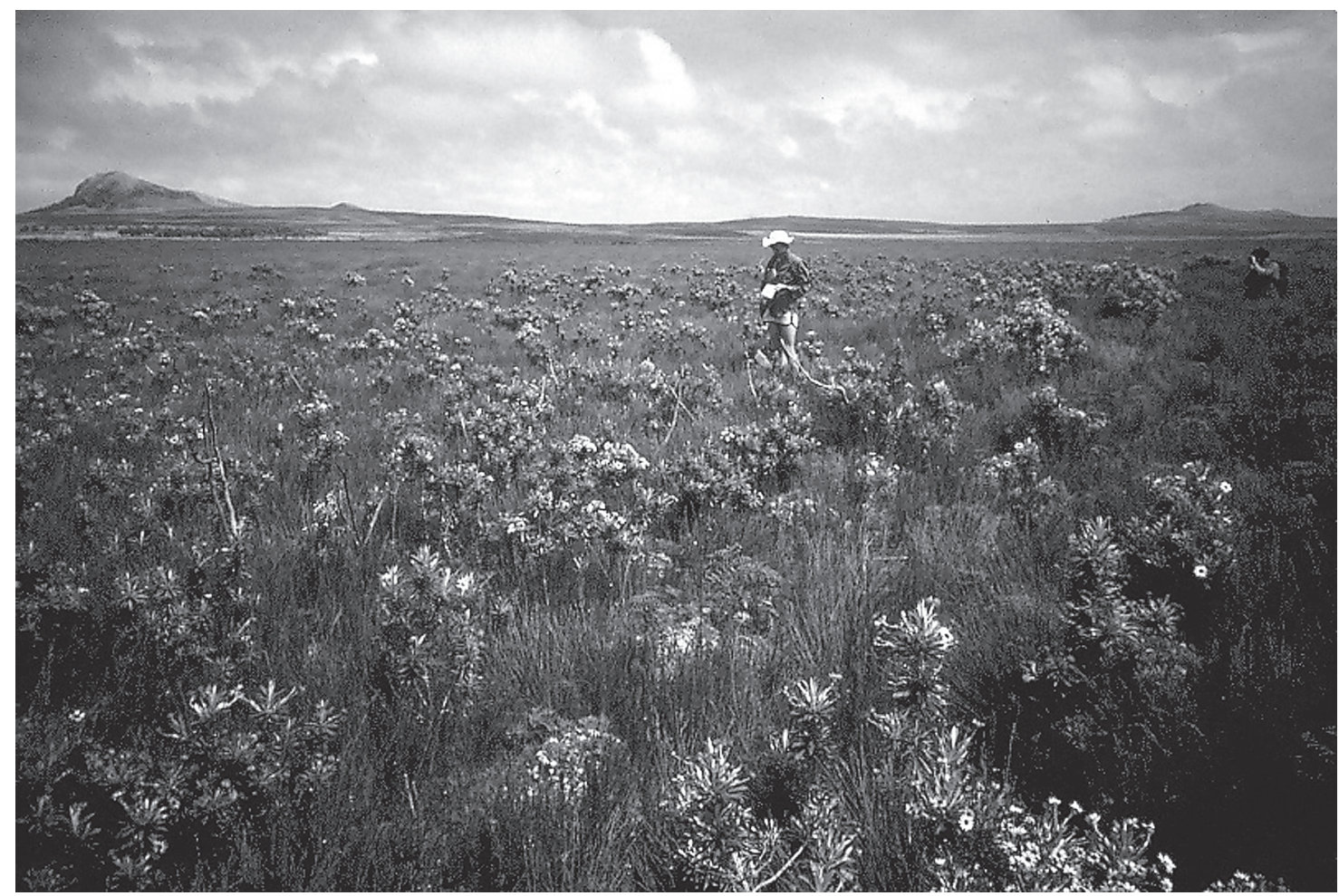

Fig. 2 Olearia semidentata (in flower) is locally common at Ocean Mail and grows in association with Sporadanthus traversii.

(Pterodroma magentae). The peat basin was dominated by $S$. traversii up to $1.5 \mathrm{~m}$ tall, with $D$. scoparium a frequent associate and $O$. semidentata and $G$. dicarpa locally present. Understorey species include a variety of non-vascular species (e.g., Sphagnum australe, Dicranum billardierei, Riccardia cochleata) and several herbs (e.g., Drosera binata), grasses (e.g., Hierochloe redolens), and ferns (e.g., Blechnum procerum). Mosaics of wetter areas occurred within the basin in which $S$. traversii was replaced by low-growing vegetation of mainly Sphagnum falcatulum, with Isolepis distigmatosa, Marchantia berteroana, and $S$. australe locally common.

\section{METHODS}

\section{Vegetation and peat sampling}

Sampling was carried out between 6 and 9 February 2001, when Chatham Island was experiencing unusually dry conditions (c. $80 \%$ of normal rainfall had been experienced since mid-winter (July) 2000; National Institute of Water and Atmospheric Research unpubl. climate data). We established transects from the margin to the centre of each peatland to represent the vegetation patterns across the bogs. Sampling sites were marked every $50 \mathrm{~m}$ and a $2 \mathrm{~m} \times 2 \mathrm{~m}$ plot was set out for vegetation and peat sampling. The plot size was determined by using the species/area curve technique for calculating minimal sampling area (Mueller-Dombois \& Ellenberg 1974), and was the same size used for Waikato restiad bogs (Clarkson et al. 2004). In the more modified and heterogeneous Lake Rotokawau system, additional plots were sampled in vegetation types not or poorly represented in the original sample, e.g., vegetation affected by stock. Eleven plots were sampled at Ocean Mail, 12 at Lake Rotokawau, 2 at Rakautahi, and 11 at Tuku, a total of 36 (Appendix 1).

At each plot the \% cover for canopy species (as defined by Atkinson 1962) was assessed, the 


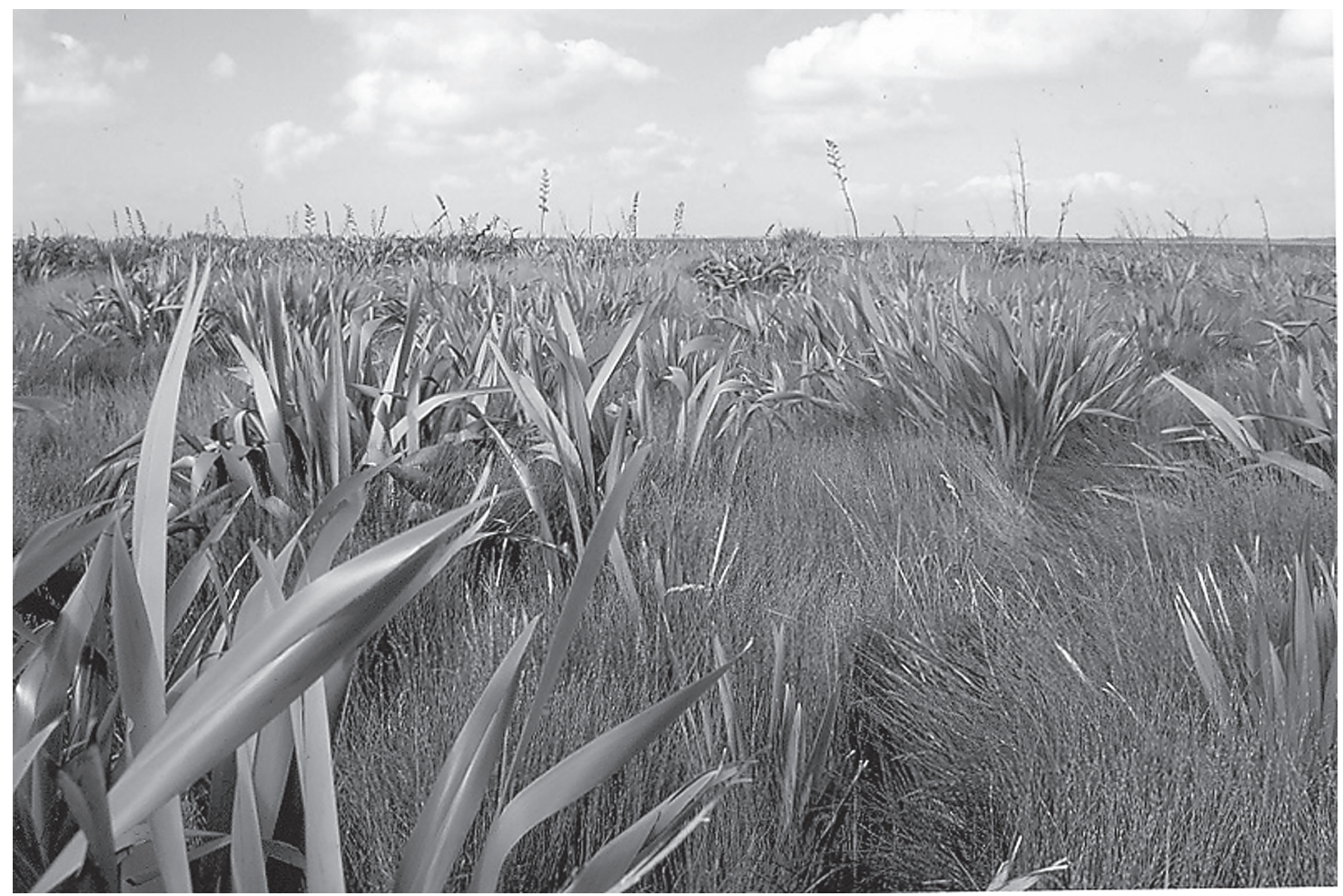

Fig. 3 Phormium tenax, Apodasmia similis, and Sporadanthus traversii near Lake Kaimoumi, Ocean Mail. The rush-like restiad species are difficult to distinguish in the photo but the ratio of Sporadanthus to Apodasmia recorded at this site (plot OM10) was about 2:1.

maximum height for each species measured, and all vascular and non-vascular plant species listed (see Appendix 2). The degree of modification caused by stock access was ranked on a 3-point scale: $0=$ no visible stock damage, $1=$ minor foliage browsing or trampling, 2 = medium-severe foliage browsing and/ or trampling damage. In addition, modification by fire was assessed as: $0=$ most recent fire $>8$ years ago, 1 = fire $2-8$ years ago (Ocean Mail fire was late 1994), and 2 = fire $0-2$ years ago (Rakautahi fire was 1999).

Peat decomposition status was determined using the qualitative von Post scale (von Post \& Granlund 1926; Clymo 1983) ranging from 1 (least decomposed) to 10 (highly decomposed). This was assessed in the field by taking a handful of peat from the uppermost $10 \mathrm{~cm}$ and squeezing; the consistency of the remaining peat and the colour of squeeze water were compared against a scale of attributes.

Two undisturbed cores were obtained from the surface layer of each plot by cutting steel liners (100 $\mathrm{mm}$ diam. by $75 \mathrm{~mm}$ deep) into the peat, and then sealed in plastic bags. In the laboratory, one core was cut into cubes $\left(1 \mathrm{~cm}^{3}\right)$ and stored at $4{ }^{\circ} \mathrm{C}$ for a maximum of 7 days before analysis for $\mathrm{pH}$, electrical conductivity (EC), and anaerobically mineralisable $\mathrm{N}$. The other core was analysed for bulk density, moisture content, total $\mathrm{N}$, total $\mathrm{P}$, total $\mathrm{K}$, total $\mathrm{C}$, and $\mathrm{H}_{2} \mathrm{SO}_{4}$-extractable $\mathrm{P}$ (see below).

Peat $\mathrm{pH}$ was determined the day after collection; $10 \mathrm{~g}$ fresh weight of peat was mixed with $25 \mathrm{ml}$ of distilled water and left for $1 \mathrm{~h}$ before reading with a standard $\mathrm{pH}$ meter. Electrical conductivity was measured on a 1:5 ratio of fresh weight of peat to deionised water (Blakemore et al. 1987).

We measured total pools of $\mathrm{N}, \mathrm{P}$, and $\mathrm{K}$, and more available pools of $\mathrm{N}$ and $\mathrm{P}$ because these were significantly correlated with vegetation pattern and species-environment models in Waikato restiad bogs (Clarkson et al. 2004). In addition, reviews of fertilisation studies revealed N, P, and, occasionally, K to be the major limiting nutrients for plant growth in northern hemisphere peatlands (Bridgham et al. 1996; Verhoeven et al. 1996). Total N, P, and K were 


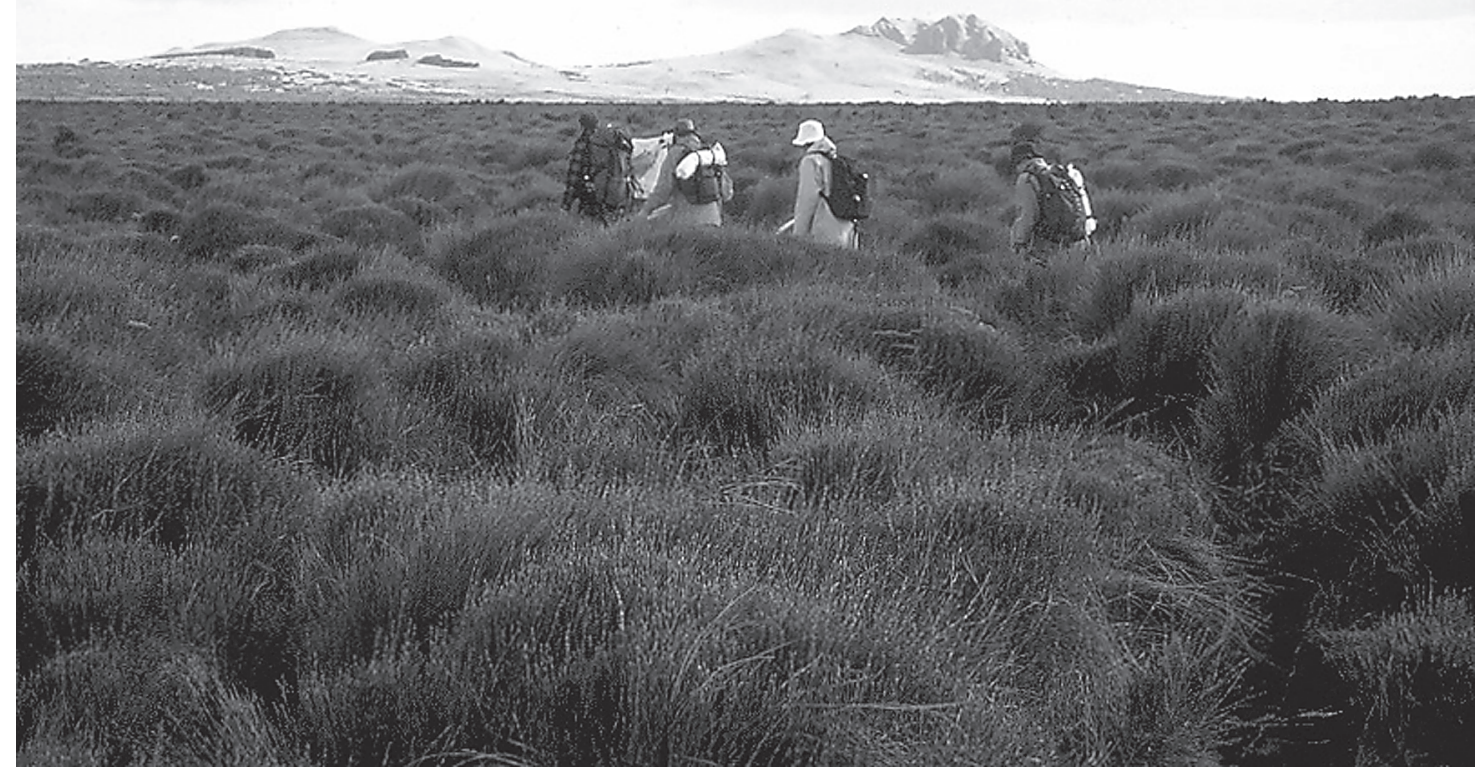

Fig. 4 Clumps of Sporadanthus traversii and shrubs of Dracophyllum scoparium typify the restiad bog vegetation at Lake Rotokawau.

measured following Kjeldahl digestion of peat using standard autoanalyser techniques (Blakemore et al. 1987). An index of available $\mathrm{N}$ was assessed using the anaerobic incubation method developed by Keeney (1982), which measures a pool of N rather than a mineralisation rate. The method, adapted by Clarkson et al. (2004) involved placing field moist peat ( $1 \mathrm{~g}$ dry weight equivalent) into $50-\mathrm{ml}$ boiling tubes and filling them with deionised water so that the peat was flooded with minimal headspace. The headspace was flushed with $\mathrm{N}_{2}$ before the tubes were sealed with rubber stoppers and incubated at $40^{\circ} \mathrm{C}$ for 7 days. After 7 days, the contents were then transferred to a $250-\mathrm{ml}$ plastic extraction bottle, and 50 $\mathrm{ml}$ of $4 \mathrm{M} \mathrm{KCl}$ was added. Extraction bottles were shaken for $1 \mathrm{~h}$, filtered, and the extract analysed for ammonium using standard autoanalyser techniques. The initial ammonium concentration of the peat was similarly determined minus the incubation period. Anaerobically mineralisable $\mathrm{N}$ was calculated as the difference between the final and initial concentration of ammonium.

Bulk density and moisture contents were measured gravimetrically after drying of the second peat core at $105^{\circ} \mathrm{C}$ for 24 hours. To measure an available pool of phosphorus, a sub-sample $(0.5 \mathrm{~g})$ of the dried peat was extracted with $0.5 \mathrm{M} \mathrm{H}_{2} \mathrm{SO}_{4}(100 \mathrm{ml})$ for 16 hours; phosphate in the extract was determined using standard autoanalyser techniques (Blakemore et al. 1987). Total $\mathrm{C}$ was determined by dry combustion of peat at $1050^{\circ} \mathrm{C}$ using a LECO carbon furnace (Blakemore et al. 1987).

As there were marked differences in bulk density between sites, all results are presented on a volumetric basis.

\section{Data analysis}

Cover scores (\%) for 44 species recorded in the 36 plots were subjected to classification (cluster analysis) and ordination to define vegetation types and determine ecological gradients. Rare species, defined as having less than $1 \%$ total cover, were omitted. The programmes used were FUSE (Agglomerative Hierarchical Fusion) and SSH (Semi-Strong-Hybrid Multidimensional Scaling), respectively, within the PATN multivariate analysis package (Belbin 1995). The SSH hybrid scaling ordination technique implements an improved version of the hybrid scaling, 


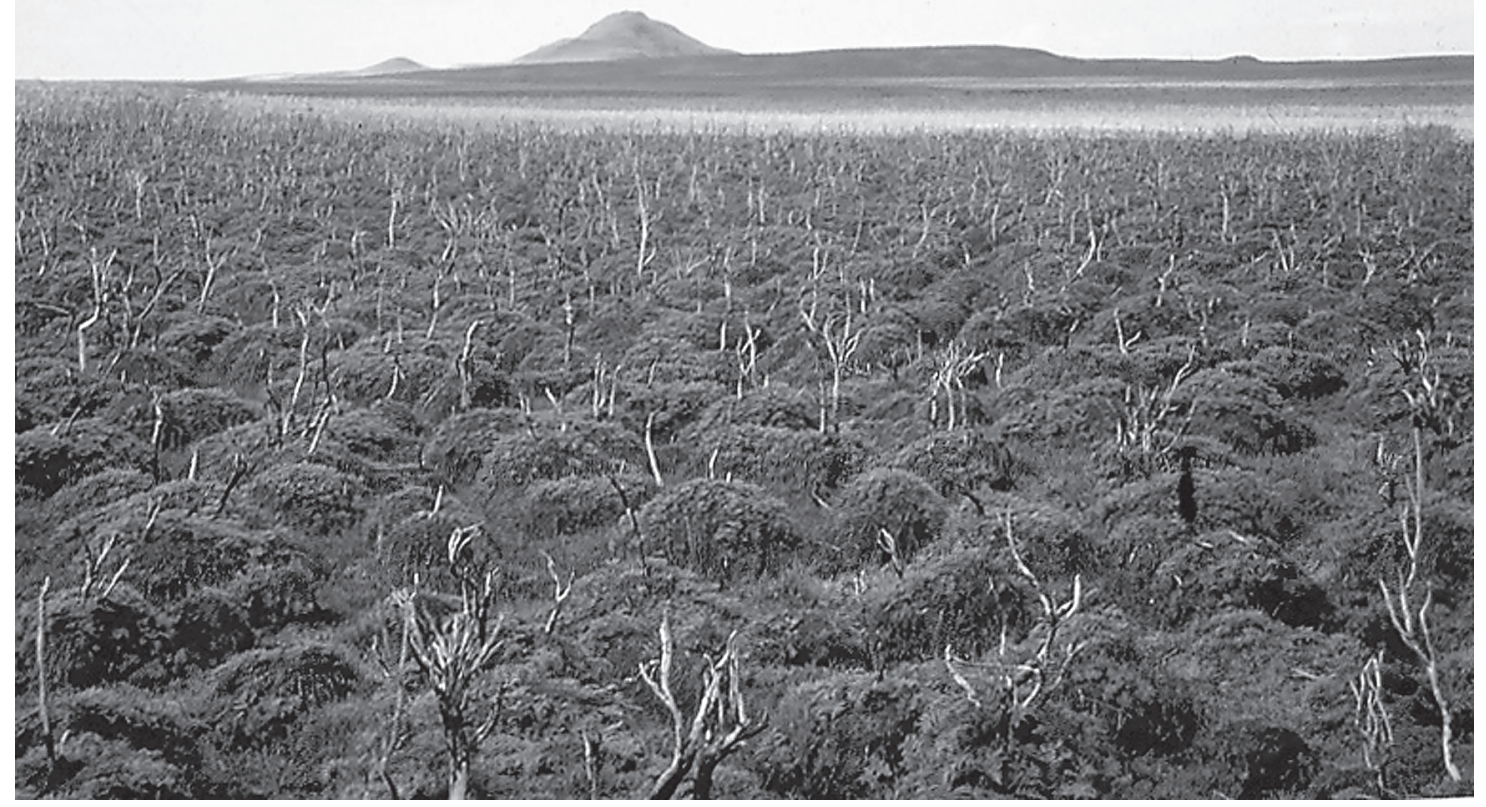

Fig. 5 Charred stems of Dracophyllum scoparium overtop clumps of Gleichenia dicarpa and Sporadanthus traversii at recently burnt Rakautahi.

which combines metric and non-metric criteria, as defined by Faith et al. (1987). It is considered to be superior to other ordination techniques, such as principal components, correspondence analysis/reciprocal averaging, and other multidimensional scaling programs, for measuring ecological distance because it is more flexible and fits output distances to input distances without squaring these distances (Minchin 1987; Belbin 1995). In all analyses we used the flexible Unweighted Pair-Group Method using Arithmetic averages (UPGMA) clustering method (with $\beta=$ -0.1 ) where equal weight is given to objects not groups, and the Bray and Curtis association measure, which consistently performed well in previous data testing (Faith et al. 1987).

In the ordination analysis, six marginal plots of non-restiad bog species were separated on Axis 3, indicating markedly dissimilar floristic composition from most of the data. As we were particularly interested in exploring species:environmental relationships in restiad bogs, the plots were omitted and the classification and ordination analyses repeated $(=30$ plots, 38 species; restiad bog data set). The resulting two-dimensional ordination with a stress value of 0.1601 was considered to summarise the data adequately (see Belbin 1995), as solutions of other dimensions $(1 \mathrm{D}$ stress $=0.3327,3 \mathrm{D}$ stress $=0.0919$, 4D stress $=0.0613)$ did not markedly change ecological interpretability.

Five vegetation types were defined by the FUSE classification of the restiad bog data set. For each type, the environmental and modification data $(\mathrm{pH}$, von Post, bulk density, moisture, conductivity, total $\mathrm{N}, \mathrm{P}, \mathrm{K}, \mathrm{C}$, available $\mathrm{P}$, available $\mathrm{N}$, browse damage, and fire) were summarised using box plots (SYSTAT version 7; Wilkinson 1997).

The environmental data and plot ordination scores were then analysed using a vector-fitting approach to examine species-environment responses. We implemented Principal Axis Correlation (PCC) within PATN, a multiple-linear regression program designed to see how well a set of environmental attributes can be fitted into an ordination space. Vectors were plotted on the two-dimensional plot ordination to indicate the direction (angle of vector) of best fit for each of the environmental variables and the strength of the correlation (length of vector) in that direction. 


\section{RESULTS}

\section{Vegetation classification and peat properties}

The vegetation characteristics of the groups defined by the classification of the restiad bog data set are summarised in Table 1. Group 1 (Spo-Apo) comprised two plots dominated by the two restiad species S. traversii and Apodasmia similis, together with Phormium tenax from the lake (south-western) end of the Ocean Mail transect. Group 2 (Apo) was a single plot dominated by Apodasmia similis from the coastal (northern) margin of Ocean Mail, in which S. traversii was absent. Group 3 (Spo) was the largest group, being S. traversii-dominated plots of the large central areas typical of intact restiad bogs. Groups 4 (Dra) and 5 (Gle) were from sites modified by browsing or recent fire and were dominated by Dracophyllum scoparium and Gleichenia dicarpa, respectively. Of all the groups, Group 5 (Gle) was the most modified, and had the lowest vegetation height and the highest number of species in the canopy. Plots in this group were characterised by an open, usually heavily browsed and broken canopy, producing conditions favourable for establishment of small herbaceous plants (e.g., Lobelia anceps, Nertera depressa, Gentiana chathamica), including many naturalised species, e.g., Hypochaeris radicata, Leontodon taraxacoides, Anthoxanthum odoratum, and Holcus lanatus.

The most frequent non-vascular species recorded in the restiad bog plots was Sphagnum australe, which occurred in the central S. traversii-dominated sites of the more intact bogs (Group 3). Floristically, the non-vascular component of Group 4 (Dra) plots was most similar to Group 3 (Spo), both having occasional Riccardia cochleata, Dicranum billardierei, and Cladia retipora.

The environmental data for the five restiad bog groups are presented in Fig. 6 (plot data in Appendix 1) to clarify vegetation:environmental patterns. Overall, the relatively unmodified Group 3 (Spo) plots had low levels of total nitrogen, total phosphorus, total potassium, available nitrogen, and available phosphorus. In contrast, the most modified Group 5 (Gle) plots typically had peat with high levels of nutrients, and low moisture content. Group 1 (Apo) and Group 2 (Spo-Apo), consisting of relatively unmodified plots from the transect margins, had relatively high $\mathrm{pH}$ and nutrient and moisture contents. Peat nutrients of the second modified group (Group 4 Dra) were only marginally elevated compared with Group 3 (Spo).

Table 1 Summary of vegetation characteristics of classification groups for the restiad bog data set. Means with standard deviations in parentheses are given for the total species (vascular and non-vascular) number, maximum vegetation height, and cover (\%) for the nine most common species.

\begin{tabular}{|c|c|c|c|c|c|}
\hline Vegetation type & $\begin{array}{c}1 \\
\text { Sporadanthus } \\
\text { traversii- } \\
\text { Apodasmia similis }\end{array}$ & $\begin{array}{l}\text { Apodasmia } \\
\text { similis }\end{array}$ & $\begin{array}{c}\text { Sporadanthus } \\
\text { traversii }\end{array}$ & $\begin{array}{l}\text { Dracophyllum } \\
\text { scoparium }\end{array}$ & $\begin{array}{l}\text { Gleichenia } \\
\text { dicarpa }\end{array}$ \\
\hline Code & Spo-Apo & Аро & Spo & Dra & Gle \\
\hline Number of plots & 2 & 1 & 18 & 3 & 6 \\
\hline Canopy species number & (0) & 5 & $4.6 \quad(3.7)$ & $8.7 \quad(6.7)$ & $12.8(6.8)$ \\
\hline Total species number & $(2.8)$ & 14 & $9.4(3.0)$ & $9.7 \quad(7.4)$ & $14.7(6.2)$ \\
\hline Vascular species number & $(2.8)$ & 14 & $7.6(3.2)$ & $7.33(5.1)$ & $14.2(6.4)$ \\
\hline Non-vascular species number & 0 & 0 & $1.8(1.7)$ & $2.3 \quad(2.3)$ & $(1.2)$ \\
\hline Vegetation height(m) & $1.7(0.1)$ & 1.0 & $1.0(0.2)$ & $1.2(0.8)$ & $0.6 \quad(0.3)$ \\
\hline Apodasmia similis cover & $27.5 \quad(3.5)$ & 70 & 0 & 0 & 0 \\
\hline Baumea tenax cover & 0 & 0 & $0.5(1.2)$ & $18.7(20.1)$ & $9.8(12.6)$ \\
\hline Cyathodes robusta cover & 0 & 0 & 0 & 0 & $7.8(8.3)$ \\
\hline Dracophyllum scoparium cover & $0.5 \quad(0.0)$ & 1 & $16.1 \quad(9.8)$ & $42.7(21.9)$ & $5.3(6.1)$ \\
\hline Gleichenia dicarpa cover & 0 & 0 & $8.4(10.1)$ & $2.3 \quad(2.5)$ & $33.5(10.2)$ \\
\hline Olearia semidentata cover & 0 & 0 & $5.5(8.1)$ & 0 & 0 \\
\hline Phormium tenax cover & $21.0(12.7)$ & 0 & $0.3(0.9)$ & 0 & $0.1 \quad(0.2)$ \\
\hline Pteridium esculentum cover & $10.5(13.4)$ & 25 & $0.1 \quad(0.2)$ & 0 & $3.3(7.7)$ \\
\hline Sporadanthus traversii cover & $37.5 \quad(3.5)$ & 0 & $66.2(13.9)$ & $(15.0)$ & $11.5(10.1)$ \\
\hline
\end{tabular}



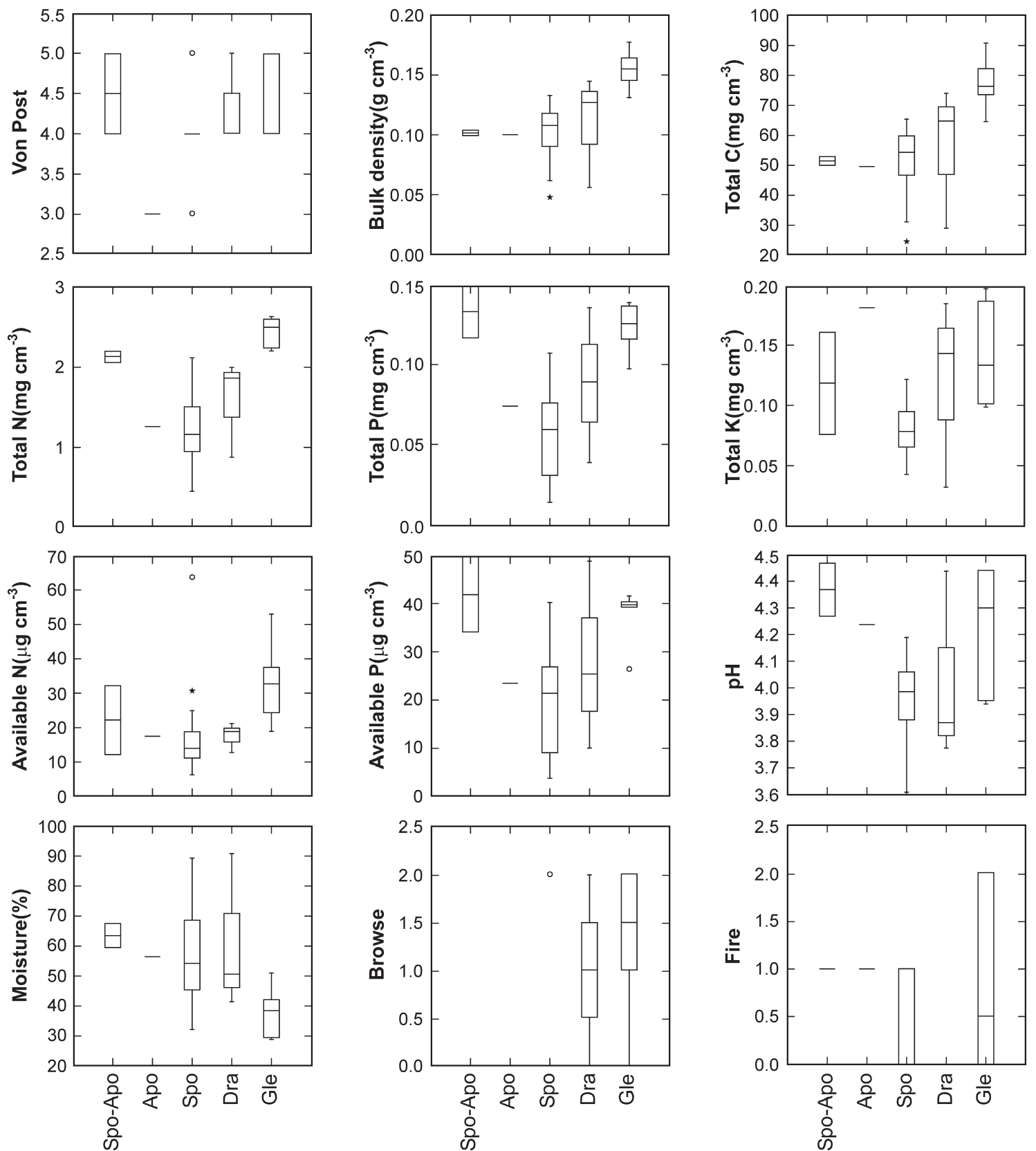

Fig. 6 Box plot summary showing medians, and upper and lower quartiles, for environmental data in each of the vegetation types (determined from the classification). Apo, Apodasmia similis; Spo, Sporadanthus traversii; Dra, Dracophyllum scoparium; Gle, Gleichenia dicarpa. 


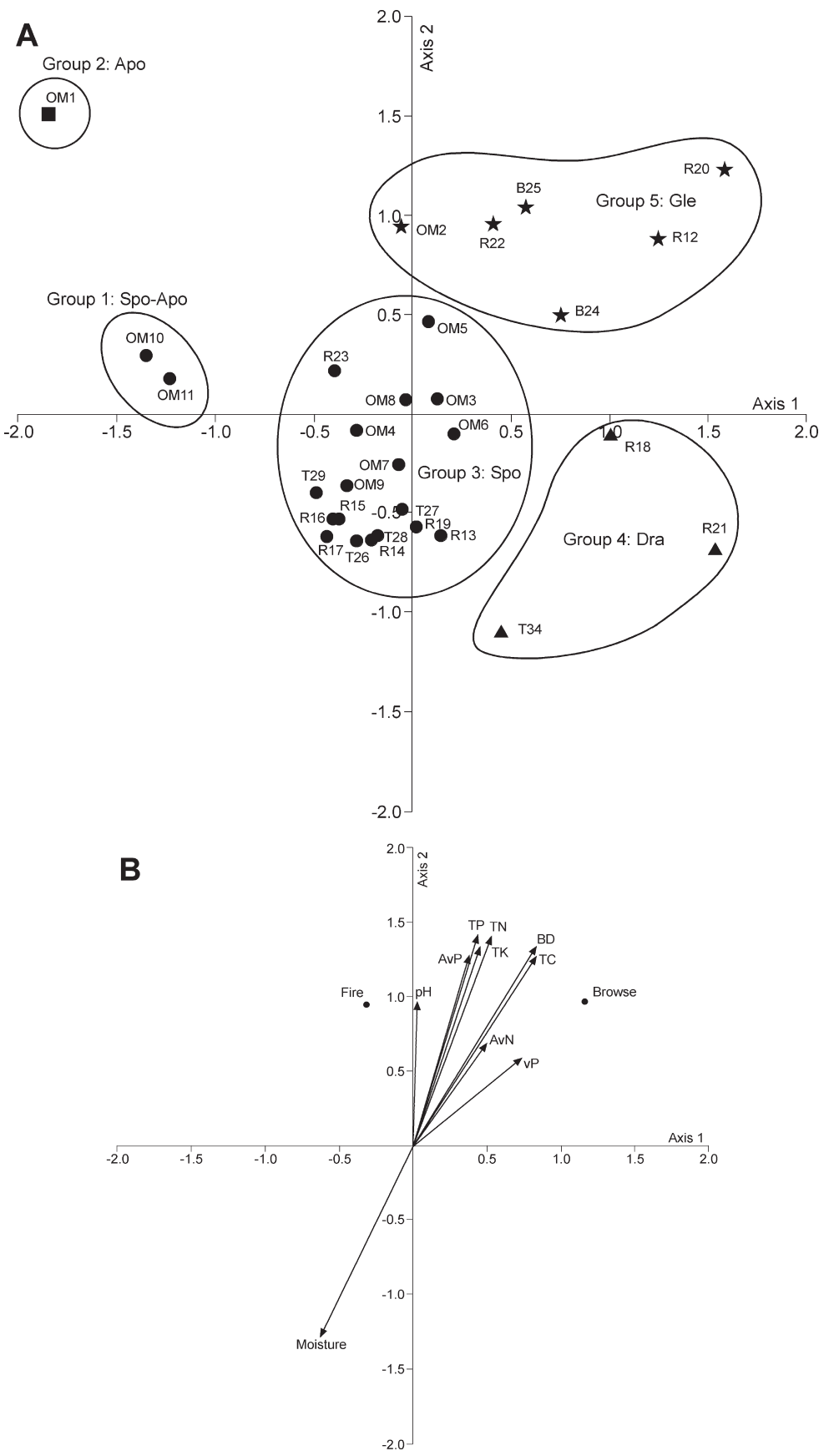

Fig. 7 A,Two-dimensional ordination of 30 plots based on canopy cover of 38 species (= restiad bog plant species data set). The vegetation type groups have been superimposed (codes as in Fig. 6). The dominant species for each plot are: Sporadanthus traversii (circles), Gleichenia dicarpa (stars), Dracophyllum scoparium triangles), Apodasmia similis (square). Bog codes with plot number: OM, Ocean Mail; R, Lake Rotokawau; B, Rakautahi; T, Tuku; B, Species:environment biplot analysis correlation vectors are shown for those environmental variables that are significantly correlated $(P$ $<0.05)$ to the ordination axis scores. Fire and browse variables (categorical data) are shown as points.

\section{Plot ordination and environmental correlation} vectors

A two-dimensional ordination of the 30-plot restiad bog data set, overlaid with the dominant species at each plot and the cluster analysis groups, indicated floristic trends (Fig. 7A). The plots are arranged along Axis 1 from marginal plots in which $A$. similis was a prominent component (low Axis 1 scores), through those from central intact bogs dominated by $S$. traversii, to those that have been modified by recent fire or browsing and in which $S$. traversii becomes increasingly scarce.

The species-environmental biplot analysis (Fig. 7B) based on the plot ordination summarises the 


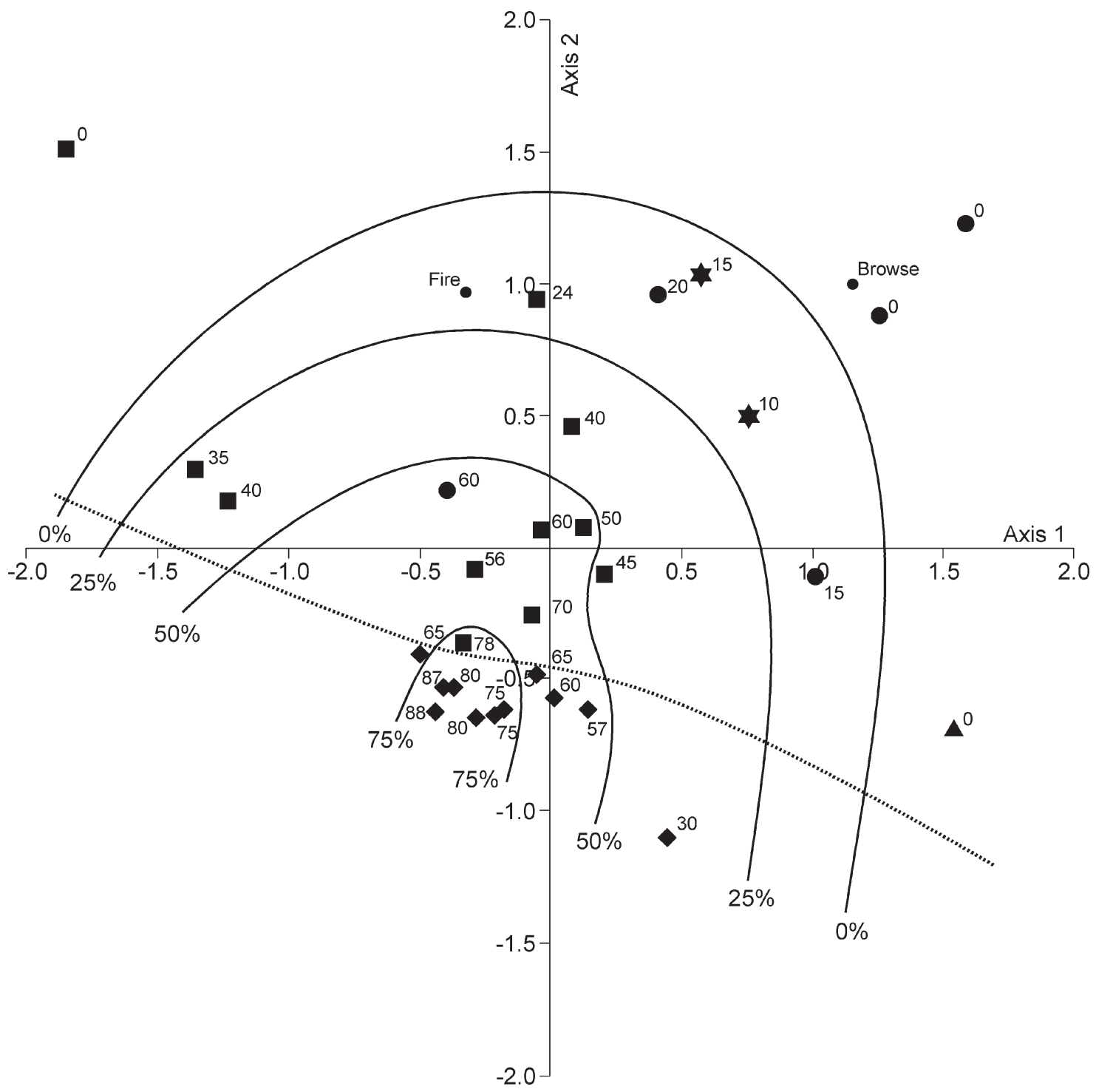

Fig. 8 Plot ordination overlaid with Sporadanthus traversii cover values and type of modification at each site. Contour lines are Sporadanthus cover. Dotted line separates modified (above) and unmodified (below) plots. Modification: high browse damage, no recent fire (circles); low browse damage, burnt 1999 (stars); low browse damage, no recent fire (triangle); no browse damage, burnt 1994 (squares); no browse damage, no recent fire (diamonds).

relationships between species abundances and those environmental variables that were significant $(P<$ $0.05)$. The length of the correlation vector indicates the degree of correlation. Plots dominated by Gleichenia dicarpa (Group 5) are associated with high nutrient levels (total $\mathrm{N}$, total $\mathrm{P}$, total $\mathrm{K}$, available $\mathrm{P}$, available $\mathrm{N}$ ) and high total $\mathrm{C}, \mathrm{pH}$, von Post index, and browse damage. These plots also have typically low $\%$ moisture. Plots dominated by $S$. traversii (Group 3), in contrast, have higher \% moisture.

Using the percent cover values of S. traversii recorded at each plot, contour lines of equal cover ( $25 \%$ intervals) were overlaid on the plot ordination (Fig. 8) to help interpret floristic trends. The presence and type of modification has also been included. 
The figure shows that plots with the highest $S$. traversii cover occur mainly in relatively unmodified sites, and plots with lowest or zero $S$. traversii cover coincide with sites highly disturbed by stock browse (e.g., margins of Lake Rotokawau) or recent fires (Rakautahi and some Ocean Mail sites).

\section{DISCUSSION}

\section{Species:environment relationships}

The vegetation patterns in restiad bogs on Chatham Island reflect mainly a disturbance gradient. Intact bogs dominated by $S$. traversii, in association with D. scoparium and minor or localised G. dicarpa and $O$. semidentata, typically had low levels of N, P, and $\mathrm{K}$, low von Post, and relatively high moisture content. Species composition and peat characteristics were similar for both lowland and higher altitude systems (the Southern Tableland is about $200 \mathrm{~m}$ higher elevation). Although large areas of relatively unmodified peatland vegetation still occur throughout the island, much is on land that continues to be susceptible to drainage, firing, and stocking, factors which lower water tables, remove vegetation cover, and compact the peat. In addition, cattle readily browse $S$. traversii and, to a lesser extent, $D$. scoparium (Wardle et al. 1986), and in some places, e.g., several sites at Lake Rotokawau, S. traversii has been eliminated by grazing, or trampled and broken up into individual pedestals. All these factors probably contribute to increased peat decomposition and elevated nutrient levels. Margins of less affected bogs dominated by or having large components of A. similis (S. traversii, $P$. tenax, and Pteridium esculentum may also be common) also had higher nutrient levels but, in contrast to modified areas, they had higher moisture, lower total $\mathrm{C}$ levels, and lower bulk density.

The relatively high nutrient levels at Rakautahi (Appendix 1) may have been influenced by the recent fire, 18 months before sampling. Fire in North American bogs has been shown to increase fertility but only temporarily, as nutrients return to pre-fire levels within 2 years (Wilbur \& Christensen 1983). Occasional fires are a natural occurrence in New Zealand restiad bogs (e.g., Newnham et al. (1995) concluded a frequency of fire every one hundred to several hundred years in Waikato pre-human times) and the vegetation usually readily recovers to prefire condition within a few years $(6-12$ years for Waikato systems; Clarkson 1997; Norton \& de
Lange 2003). At Ocean Mail, after a fire in November 1994, seedlings of all the former dominant species (S. traversii, D. scoparium, and O. semidentata) and resprouts of other important species (e.g., $G$. dicarpa, $P$. tenax) were recorded within 4 months, and a dense vegetation cover up to $20-40 \mathrm{~cm}$ tall had established by 17 months (Walls \& Baird 1997). When we sampled at Ocean Mail, 6 years and 3 months after the fire, the canopy ranged from 0.75 to $1.5 \mathrm{~m}$ tall, comprising a mixture of species (mean $=7$ ), and the understorey was also relatively diverse. Most of the bog vegetation, particularly in the lowland sites, is probably still currently recovering from fires, because the maximum heights of $D$. scoparium, $S$. traversii, and $O$. semidentata recorded during the survey were $1.99 \mathrm{~m}, 1.46 \mathrm{~m}$, and $1.30 \mathrm{~m}$, respectively. Relatively unburnt vegetation measured at the Lake Rotokawau peatland in 1996 was dominated by $S$. traversii and $D$. scoparium, both up to $2.2 \mathrm{~m}$ tall, and formed a dense thicket that excluded most other species (de Lange et al. 1999b). Although $S$. traversii, $D$. scoparium, and $O$. semidentata regenerate readily after fire, repeated human-induced firing can eliminate them, particularly if nearby seed sources are also destroyed (Cockayne 1902; Given \& Williams 1984; Wardle et al. 1986). Replacement species include $G$. dicarpa in wetter areas, and bracken (Pteridium esculentum) on drier sites (Given \& Williams 1984). Early European settlers, from the mid 19th century on, regularly burnt the extensive areas of open-lands or "clears" (peat domes and basins dominated by $S$. traversii) to improve access for travel and palatability to stock (Kelly 1983). At the beginning of the 20th century, the combination of fire and stock was considered the major cause of vegetation modification (Cockayne 1902). Fire frequency has decreased in recent years with improved roading and use of other farming practices; however, there are approximately one or two deliberately lit or accidental fires in a Chatham Island bog every 5 years (A. Baird pers. comm. 2002).

\section{Comparison with Waikato bogs}

The environmental characteristics and species richness of intact bogs dominated ( $>40 \%$ cover) by restiad species on Chatham Island and Waikato are summarised in Table 2. Vegetation types were defined by cluster analyses, i.e., the "Sporadanthus traversii" group of Table 1 and the Waikato "Empodisma minus" and "Sporadanthus ferrugineus" groups of Clarkson et al. (2004). The Chatham Sporadanthus traversii group had significantly higher bulk density, total $\mathrm{N}$, total $\mathrm{K}$, available 
$\mathrm{P}$, and von Post index than either Waikato group, and significantly lower $\mathrm{pH}$. Between the Waikato groups, $\mathrm{pH}$ was significantly different, with Sporadanthus ferrugineus having a lower $\mathrm{pH}$ than Empodisma minus. Comparison of species richness indicated that total and vascular plant species numbers were significantly higher in the Sporadanthus traversi group than the Sporadanthus ferrugineus group.

On Chatham Island, the higher N, P, and K contents may have originated from sea birds, vast numbers of which apparently bred on Chatham Island in pre-human times (Bourne 1967). Sea birds were shown to enrich the soils $(\mathrm{N}, \mathrm{P})$ and foliage $(\mathrm{N}, \mathrm{K}$, $\mathrm{Fe}, \mathrm{Na}$ ) in and around breeding and roosting sites via guano, feathers, and bird carcasses on sub-antarctic Marion Island in the southern Indian Ocean (Smith 1976; Burger et al. 1978; Williams \& Berruti 1978; Williams et al. 1978). Enrichment of peat and foliage (total and extractable $\mathrm{N}$, extractable $\mathrm{P}, \mathrm{Ca}, \mathrm{Mg}$ ) on Beauchêne Island, Falkland Islands, was also attributed to nearby sea bird colonies (Smith \& Prince 1985). The remanence of bird-derived nutrients was demonstrated for pre-European sea bird nesting sites on mainland New Zealand, which still retained significantly higher $\mathrm{N}$ and $\mathrm{P}$ levels than nonbreeding sites 300-700 years after extinguishment of bird colonies (Hawke et al. 1999). The higher nutrient content of Chatham peat may also be the result of sea spray and strong winds. Meurk et al. (1994) measured high inputs of wind-transported oceanic ions on Campbell Island, another southern oceanic island of New Zealand. The maritime influ- ence combined with the ability of tussock-forming plants to intercept and channel aerosols (including volatilised nitrogenous compounds from sea birds) to feeding roots occupying fibrous pedestals (such as in $S$. traversii) would enhance the nutrient supply to the plant (Barrow 1983). Higher bulk densities of Chatham Island peat may be partly due to its higher wax content (average crude wax yield 9.4\%) compared with Waikato peat (average yield 4.7\%; MacPherson \& Hughson 1943).

Overall, peat depth evidence suggests that peat accumulation rates for Chatham Island and Waikato are similar. Mildenhall (1994) recorded more than $10 \mathrm{~m}$ of peat since the last glacial maximum on Chatham Island (marked by the Kawakawa Tephra $22590 \pm 230$ yr BP; Wilson et al. 1988). This peat had begun forming on previous peat soils by c. $12000 \mathrm{yr}$ BP in response to climate amelioration (Mildenhall 1994; McGlone 2002). The oldest bogs in the Waikato were initiated post-glacially, and peat depths up to $12 \mathrm{~m}$ have been recorded (Grange et al. 1939), with the major peat development occurring after c. 12000 yr BP (Hogg et al. 1987). However, there are differences in the origin and maintenance of the two peat systems. Waikato has raised bogs that were formed on poorly drained depressions on alluvial terraces associated with former river courses, and have been maintained in a relatively wet, winter rainfall and summer drought regime. The Chatham Island bogs are typically oceanic and comprise mainly blanket bogs formed on poorly drained flat, rolling, and moderately sloped terrain and, to a

Table 2 Comparison of peat properties and species richness of Sporadanthus traversii-dominated Chatham Island restiad bogs with Empodisma minus- and Sporadanthus ferrugineus-dominated Waikato restiad bogs. Means with standard deviations in parentheses are given for the vegetation types as defined by cluster analysis (Waikato data from Clarkson et al. 2004). Significantly different means are followed by different letters $(P<0.05)$.

\begin{tabular}{llll}
\hline $\begin{array}{l}\text { Vegetation type } \\
\text { (from cluster analysis) }\end{array}$ & $\begin{array}{c}\text { Sporadanthus } \\
\text { traversii }\end{array}$ & $\begin{array}{c}\text { Sporadanthus } \\
\text { ferrugineus }\end{array}$ & $\begin{array}{c}\text { Empodisma } \\
\text { minus }\end{array}$ \\
\hline Region & Chatham Island & Waikato & Waikato \\
Number of plots & 18 & 9 & 22 \\
Total K mg cm & 0.3 & $0.013(0.009) \mathrm{b}$ & $0.027(0.023) \mathrm{b}$ \\
$\mathrm{pH}$ & $4.0(0.1) \mathrm{a}$ & $4.4(0.2) \mathrm{b}$ & $4.8(0.4) \mathrm{c}$ \\
Available P mg cm & $18.6(10.7) \mathrm{a}$ & $3.4(3.2) \mathrm{b}$ & $6.2(6.1) \mathrm{b}$ \\
von Post & $4.0(0.5) \mathrm{a}$ & $1.8(0.4) \mathrm{b}$ & $2.8(1.4) \mathrm{b}$ \\
Bulk density g cm & $0.101(0.024) \mathrm{a}$ & $0.059(0.022) \mathrm{b}$ & $0.065(0.026) \mathrm{b}$ \\
Total N mg cm & $0.53(0.16) \mathrm{b}$ & $0.78(0.46) \mathrm{b}$ \\
Total P $\mu \mathrm{g} \mathrm{cm}^{-3}$ & $1.20(0.46) \mathrm{a}$ & $0.019(0.014) \mathrm{a}$ & $0.035(0.003) \mathrm{a}$ \\
Available N $\mu \mathrm{g} \mathrm{cm}^{-3}$ & $0.057(0.030) \mathrm{a}$ & $8.9(4.1) \mathrm{a}$ & $19.0(12.6) \mathrm{a}$ \\
Nonvascular species number & $17.2(13.1) \mathrm{a}$ & $1.1(1.7) \mathrm{a}$ & $1.9(2.0) \mathrm{a}$ \\
Vascular species number & $1.8(1.7) \mathrm{a}$ & $4.8(1.6) \mathrm{b}$ & $6.2(1.1) \mathrm{ab}$ \\
Total species number & $7.6(3.2) \mathrm{a}$ & $5.9(3.1) \mathrm{b}$ & $8.1(2.8) \mathrm{ab}$ \\
\hline
\end{tabular}


lesser extent, raised bogs in wetter basins. These have been maintained in a relatively dry climate by low summer temperatures, moderately high humidity, and low sunshine hours (McGlone 2002). The climatic differences suggest that natural fires would be more common in Waikato bogs, and there is ample evidence of abundant charcoal remains throughout the peat profiles (e.g., McGlone et al. 1984; Newnham et al. 1995). Although charcoal has been regularly recorded in pre-human Chatham Island peats (D. H. Mildenhall pers. comm. 2003), and there is a possibility of irregular fire, it is unlikely that fire had as important a role in the long-term history of bog development. This is because Chatham Island peatlands are much older and developed mainly during long cool moist periods of the glacials (Mildenhall 1994; McGlone 2002).

In the Waikato, the vegetation patterns within a range of differently aged bogs closely paralleled the successional sequence over time as interpreted from palaeoecological fossil evidence (Clarkson et al. 2004). The sequence was from early successional sedges (particularly Baumea rubiginosa and $B$. teretifolia), through mid-successional Empodisma minus, to late-successional Sporadanthus ferrugineus. On Chatham Island the minerotrophic plots (Groups 1 and 2) may represent younger, early successional stages of $S$. traversii bog development (Group 3), but we have no detailed microfossil or macrofossil data of temporal vegetation changes at early stages of bog development. Broad-scale pollen analyses of peat profiles have indicated that Restionaceae (Sporadanthus) dominated the oldest peats, dating back to more than $33500 \mathrm{yr} \mathrm{BP}$, and have been relatively prominent ever since (Mildenhall 1994; McGlone 2002). If the Chatham Island restiad bogs were also initiated with a sedge phase, component species were likely to have been Baumea rubiginosa, B. tenax, Carex chathamica, and $C$. sectioides, which are common on the more minerotrophic bog margins. The restiad species, Apodasmia similis, may also have been an important species in the early successional stages, as it was once dominant in minerotrophic wetlands (Cockayne 1902). It also typically intergraded into $S$. traversii vegetation (Kelly 1983), and although this vegetation type is now much reduced in extent, examples were encountered at the transect extremities at Ocean Mail.

Sporadanthus traversii has been described as probably being a mid-successional to late-successional species, like E. minus in northern North Island (de Lange et al. 1999b). Our data further suggest that in some respects $S$. traversii could be regarded as an ecological equivalent to E. minus, having an apparently comparable role in bog development on Chatham Island to E. minus in the Waikato. E. minus is the key to Waikato restiad bog development, as it occupies a wide environmental range, establishes early in fertile minerotrophic wetlands, and persists as a prominent component through to late successional ombrotrophic bogs (Clarkson et al. 2004). $S$. traversii also grows in relatively high fertility sites, as indicated by the peat characteristics of the $S$. traversii-A. similis vegetation type (Group 1 of Fig. 6 ), and it was still a relatively common component in most of the modified Gleichenia type plots (Group 5). Similarly, at the other extreme, S. traversii dominated the low-nutrient sites typical of the ombrotrophic $S$. traversii vegetation type (Group 3). In other ways $S$. traversii is more similar both physiognomically and ecologically to the smaller $E$. minus than to its closer relative, $S$. ferrugineus. For example, there were no significant differences in species richness between the Sporadanthus traversii and Empodisma minus vegetation groups (Table 2), yet differences were significant for total and vascular plant species richness between the Sporadanthus traversii and Sporadanthus ferrugineus groups. Further, $S$. traversii looks superficially like E. minus with its more slender culms and rhizomes (means for diameters of E. minus, S. traversii, and S.ferrugineus culms are $1.25,6.5$, and $12.5 \mathrm{~mm}$, and rhizomes 5 , 7.5, and $12.5 \mathrm{~mm}$, respectively; Campbell 1964; Moore \& Edgar 1976; de Lange et al. 1999b), and sprawling habit in the absence of supporting vegetation. Like E. minus, $S$. traversii regenerates readily from seed after fire and can dominate plant communities within months, in contrast to $S$. ferrugineus, which usually takes several years to attain pre-fire composition (Clarkson 1997; de Lange et al. 1999b).

Morphologically, however, the roots of $S$. traversii and $E$. minus have some marked differences. $S$. traversii is more similar to $S$. ferrugineus in having a hairless rhizome with deeply descending tubular roots whereas the E. minus rhizome is densely hairy with smaller roots mostly confined to the upper peat layers (Campbell 1964; Wardle et al. 1986). The most notable feature of E. minus is the mass of upward-growing fine roots and root hairs (=cluster roots; Lamont 1982; Neumann \& Martinoia 2002), which grow at and above the peat surface, eventually forming the main bulk of the peat (Campbell 1964). Sporadanthus traversii and $S$. ferrugineus do not have the abundant surface layer of cluster roots, but the roots do develop the cluster 
habit as described for the Australian species of Sporadanthus (Meney \& Pate 1999). Young plants of S. traversii and S.ferrugineus have been observed to develop abundant fine roots that bind the upper layers of peat both in glasshouse trials and outdoor plantings in the Waikato region. However, unlike $E$. minus, these roots remain below the peat surface (BRC unpubl. data). Despite differences in root structure, E. minus forms the bulk of the peat in Waikato raised bogs and $S$. traversii is the main peat former in Chatham Island raised bogs, thus providing further evidence of functional equivalence between these two species.

\section{ACKNOWLEDGMENTS}

We thank Department of Conservation for permission to undertake this study on DOC-administered land and for logistical support, particularly from Amanda Baird, Mike Ogle, John Mason, and Anna Ogle. We thank Mrs H. Daymond, Mr and Mrs M. Dix, and Mr T. Anderson for permission to access private land. Corinne Watts and Gary Barker assisted in the field; Maja Vojvodic-Vukovic provided technical expertise, David Glenny identified the liverworts, and Jessica Beever identified the mosses. Matt McGlone, Peter Johnson, Jill Rapson, and an anonymous referee commented on the manuscript, and Matt McGlone contributed meaningful discussions on fire and peat growth. Funding was provided by the Foundation for Research, Science and Technology (contract C09X0205). This research is dedicated to the memory of Mary Matilda Clarkson (nee Jacobs), born Rangiauria, Chatham Islands, in 1877.

\section{REFERENCES}

Atkinson, I. A. E. 1962: Semi-quantitative measurements of canopy composition as a basis for mapping vegetation. Proceedings of the New Zealand Ecological Society 9: 1-8.

Atkinson, I. A. E. 1996: Major habitats. In: Department of Conservation ed. The Chatham Islands heritage and conservation. Christchurch, Canterbury University Press. Pp. 49-61.

Barrow, C. J. 1983: Palynological studies in South Georgia: IV. Profiles from Barff Peninsula and Annenkov Island. British Antarctic Survey Bulletin 58: 61-70.

Belbin, L. 1995: PATN: Pattern analysis package. Technical reference. Canberra, CSIRO Division of Wildlife and Ecology.

Blakemore, L. C. 1958: The chemistry of organic soils. New Zealand Soil News 2: 46-52.
Blakemore, L. C.; Searle, P. L.; Daly, B. K. 1987: Methods for chemical analysis of soils. New Zealand Soil Bureau Scientific Report 80. Lower Hutt, DSIR.

Bourne, W. R. P. 1967: Subfossil petrel bones from the Chatham Islands. The Ibis 109: 1-7.

Bridgham, S. D.; Pastor, J.; Janssens, J. A.; Chapin, C.; Malterer, T. J. 1996: Multiple limiting gradients in peatlands: a call for a new paradigm. Wetlands 16: 45-65.

Burger, A. E.; Lindeboom, H. J.; Williams, A. J. 1978: The mineral and energy contributions of guano of selected species of birds to the Marion Island terrestrial system. South African Journal of Antarctic Research 8: 59-70.

Campbell, E. O. 1964: The restiad peat bogs at Motumaoho and Moanatuatua. Transactions of the Royal Society of New Zealand, Botany 2: 219-227.

Campbell, E. O. 1983: Mires of Australasia. In: Gore, A. J. P. ed. Ecosystems of the world 4A Mires: swamp, bog, fen and moor. Amsterdam, The Netherlands, Elsevier Scientific Co. Pp. 153-180.

Campbell, I. B. 1996: Geology. In: Department of Conservation $e d$. The Chatham Islands heritage and conservation. Christchurch, Canterbury University Press. Pp. 14-48.

Clarkson, B. R. 1997: Vegetation recovery following fire in two Waikato peatlands at Whangamarino and Moanatuatua. New Zealand Journal of Botany 35: 167-179.

Clarkson, B. R.; Schipper, L. A.; Lehmann, A. 2004: Vegetation and peat characteristics in the development of lowland restiad bogs, North Island, New Zealand, since c. $13000{ }^{14} \mathrm{C}$ years BP. Wetlands 24: 133-151.

Clymo, R. S. 1983: Peat. In: Gore, A. J. P. ed. Ecosystems of the world 4A Mires: swamp, bog, fen and moor. Amsterdam, The Netherlands, Elsevier Scientific Co. Pp. 159-224.

Cockayne, L. 1902: A short account of the plant-covering of Chatham Island. Transactions and Proceedings of the New Zealand Institute 34: 243-325.

de Lange, P. R.; Sawyer, J. W. D.; Ansell, R. 1999a: Checklist of indigenous vascular plant species recorded from Chatham Islands. Wellington, Department of Conservation.

de Lange, P. R.; Heenan, P. B.; Clarkson, B. D.; Clarkson, B. R. 1999b: Sporadanthus in New Zealand. New Zealand Journal of Botany 37: 413-431.

Faith, D. P.; Minchin, P. R.; Belbin, L. 1987: Compositional dissimilarity as a robust measure of ecological distance. Vegetatio 69: 57-68. 
Given, D. R. 1996: Flora. In: Department of Conservation $e d$. The Chatham Islands heritage and conservation. Christchurch, Canterbury University Press. Pp. 80-92.

Given, D. R.; Williams, P. A. 1984: Conservation of Chatham Island flora and vegetation. Christchurch, Botany Division, DSIR.

Grange, L. I.; Taylor, N. H.; Sutherland, C. F.; Dixon, J. K.; Hodgson, L.; Seelye, F. T. 1939: Soils and agriculture of part of Waipa County: Soils. DSIR Bulletin 76: 30-63.

Hawke, D. J.; Holdaway, R. N.; Causer, J. E.; Ogden, S. 1999: Soil indicators of pre-European seabird breeding in New Zealand at sites identified by predator deposits. Australian Journal of Soil Research 37: 103-113.

Hogg, A. G.; Lowe, D. J.; Hendy, C. H. 1987: University of Waikato radiocarbon dates I. Radiocarbon 29: 263-301.

Keeney, D. R. 1982: Nitrogen-availability indices. In: Page, A. L. ed. Methods of soil and plant analysis: part 2 chemical and microbiological properties. 2nd ed. Madison, Wisconsin SSSA. Pp. 711-735.

Kelly, G. C. 1971: Reserves in the Chatham Islands. Unpublished Botany Division, DSIR Report, held at Landcare Research, Lincoln, New Zealand.

Kelly, G. C. 1978: Proposed Chatham Island national park. Unpublished Botany Division, DSIR Report, held at Landcare Research, Lincoln, New Zealand.

Kelly, G. C. 1983: Distribution and ranking of remaining areas of indigenous vegetation in the Chatham Islands. Unpublished Botany Division DSIR Vegetation Report 501, held at Landcare Research, Lincoln, New Zealand.

Lamont, B. 1982: Mechanisms for enhancing nutrient uptake in plants, with particular reference to Mediterranean South Africa and western Australia. The Botanical Review 48: 597-689.

McGlone, M. S. 2002: The Late Quaternary peat, vegetation and climate history of the Southern Oceanic Islands of New Zealand. Quaternary Science Reviews 21: 683-707.

McGlone, M. S.; Nelson, C. S.; Todd, A. J. 1984: Vegetation history and environmental significance of pre-peat and surficial peat deposits at Ohinewai, Lower Waikato lowland. Journal of the Royal Society of New Zealand 14: 233-244.

MacPherson, E. O.; Hughson, W. G. 1943: Wax from Chatham Island peat. New Zealand Journal of Science and Technology 25: 1-31.
Meney, K. A.; Pate, J. S. 1999: Australian rushes: biology, identification and conservation of Restionaceae and allied families. Nedlands, Western Australia, University of Western Australia Press.

Meurk, C. D.; Foggo, M. N.; Thomson, B. M.; Bathurst, E. T. J. 1994: Ion-rich precipitation and vegetation pattern on subantarctic Campbell Island. Arctic and Alpine Research 26: 281-289.

Mildenhall, D. C. 1994: Palynological reconnaissance of early Cretaceous to Holocene sediments, Chatham Islands, New Zealand. Institute of Geological and Nuclear Sciences Monograph 7. 206 p.

Minchin, P. R. 1987: An evaluation of the robustness of techniques for ecological ordination. Vegetatio 69: 89-107.

Moore, L. B.; Edgar, E. 1976: Flora of New Zealand. Vol. II. Wellington, Government Printer.

Mueller-Dombois, D.; Ellenberg, H. 1974: Aims and methods of vegetation ecology. New York, John Wiley $\&$ Sons.

New Zealand Meteorological Service 1973: Summaries of climatological observations to 1970. New Zealand Meteorological Service Miscellaneous Publication 143. Wellington, Government Printer.

Neumann, G.; Martinoia, E. 2002: Cluster roots - an underground adaptation for survival in extreme environments. Trends in Plant Science 7: 162-167.

Newnham, R. M.; de Lange, P. J.; Lowe, D. J. 1995: Holocene vegetation, climate and history of a raised bog complex, northern New Zealand based on palynology, plant macrofossils and tephrochronology. The Holocene 5: 267-282.

Norton, D. A.; de Lange, P. J. 2003: Fire and vegetation in a temperate peat bog: implications for the management of threatened species. Conservation $\mathrm{Bi}$ ology 17: 138-148.

Smith, R. I. L.; Prince, P. A. 1985: The natural history of Beauchêne Island. Biological Journal of the Linnean Society 24: 233-283.

Smith, V. R. 1976: Standing crop and nutrient status of Marion Island (sub-Antarctic). Journal of South African Botany 42: 231-263.

Thompson, C. S. 1983: The weather and climate of the Chatham Islands. New Zealand Meteorological Service Miscellaneous Publication 115(13). Wellington, Government Printer.

Verhoeven, J. T. A.; Koerselmann, W.; Meuleman, A. F. 1996: Nitrogen- or phosphorus-limited growth in herbaceous, wet vegetation: relations with atmospheric inputs and management regimes. Trends in Ecology \& Evolution 11: 494-497. 
von Post, L.; Granlund, E. 1926: Sodra Sveriges torvtillganger I. Sveriges geologiska undersökning, Serie C, Avhandlingar och uppsatser 335: 1-127.

Walls, G.; Baird, A. 1995: Winds of change: monitoring vegetation condition and trend in the Chatham Islands. Conservancy Advisory Science Notes 130. Wellington, Department of Conservation.

Walls, G.; Baird, A. 1997: Holes in the fence: The vegetation of Chatham Island reserves, 1990-1996. Conservancy Advisory Science Notes 156. Wellington, Department of Conservation.

Wardle, P. 1991: Vegetation of New Zealand. Cambridge, Cambridge University Press.

Wardle, P.; Atkinson, I. A. E.; Given, D. R.; Molloy, B. J. P.; Brown, C. M.; Manning, D. 1986: Botany Division visit to the Chatham Islands FebruaryMarch 1985. Unpublished report to the Liquid Fuels Trust Board from Botany Division, DSIR.

Wilbur, R. B.; Christensen, N. L. 1983: Effects of fire on nutrient availability in a North Carolina coastal plain pocosin. American Midlands Naturalist 110: 54-61.
Wilkinson, L. 1997: SYSTAT 7.0. Chicago IL, SPSS.

Williams, A. J.; Berruti, A. 1978: Mineral and energy contributions of feathers moulted by penguins, gulls and cormorants to the Marion Island terrestrial ecosystem. South African Journal of Antarctic Research 8: 71-74.

Williams, A. J.; Burger, A. E.; Berruti, A. 1978: Mineral and energy contributions of carcasses of selected species of seabirds to the Marion Island terrestrial ecosystem. South African Journal of Antarctic Research 8: 53-59.

Wills-Johnson, T. M. K. 1996: Introduction. In: Department of Conservation ed. The Chatham Islands heritage and conservation. Christchurch, Canterbury University Press. Pp. 11-20.

Wilson, C. J. N.; Switsur, V. R.; Ward, A. P. 1988: A new ${ }^{14} \mathrm{C}$ age for the Oruanui (Wairakei) eruption, New Zealand. Geological Magazine 125: 297-300.

Wright, A. C. S. 1959: Soils of Chatham Island (Rekohu). Soil Bureau Bulletin 19. Wellington, New Zealand, DSIR. 


\begin{tabular}{|c|c|c|}
\hline 兰 & 范 & 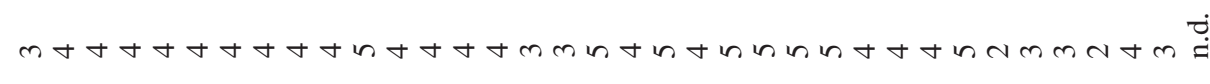 \\
\hline 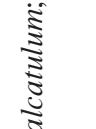 & 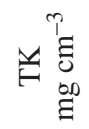 & 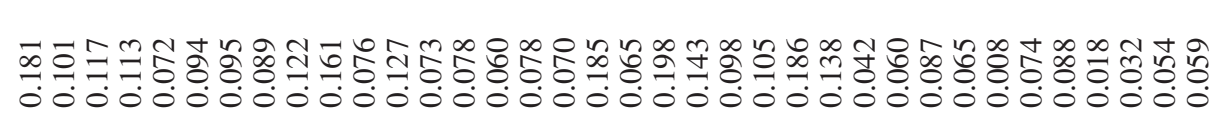 \\
\hline$\stackrel{2}{5}$ & 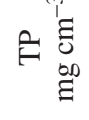 & 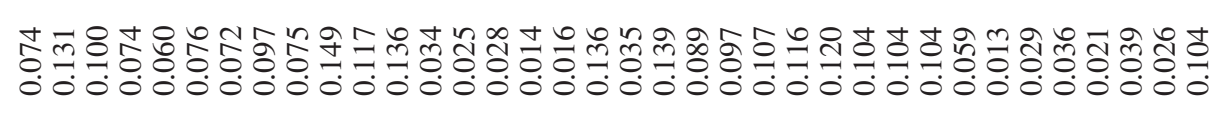 \\
\hline$\because *$ & Z & 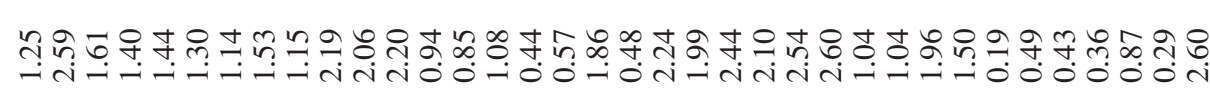 \\
\hline 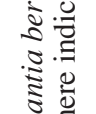 & 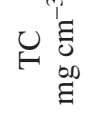 & 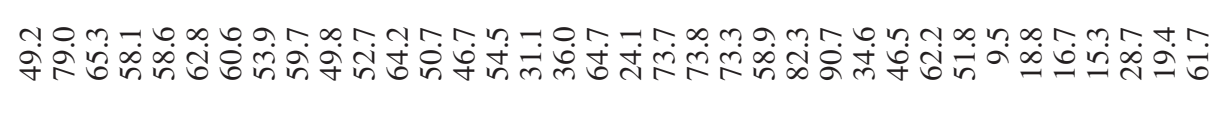 \\
\hline 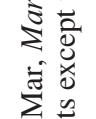 & 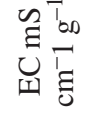 & 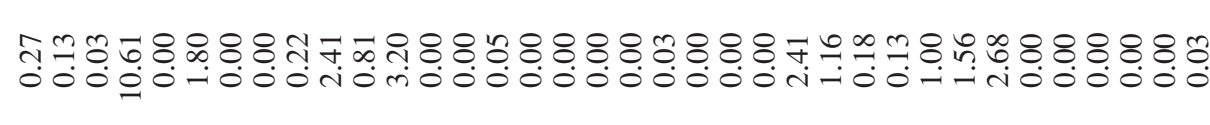 \\
\hline 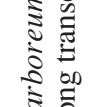 & 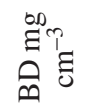 & 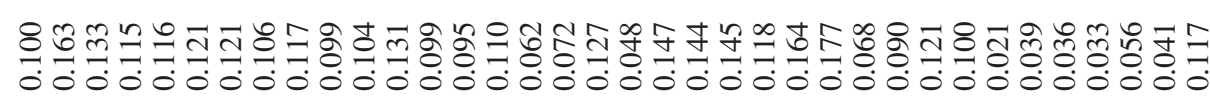 \\
\hline 永离 & 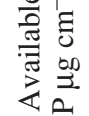 & 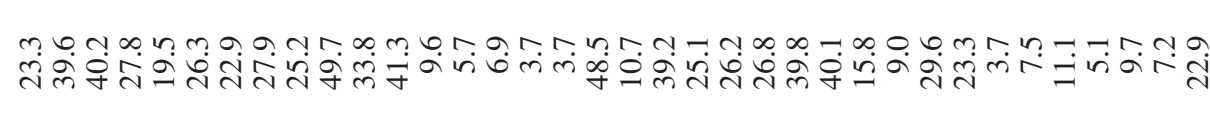 \\
\hline 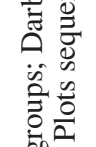 & 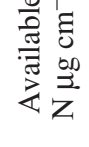 & 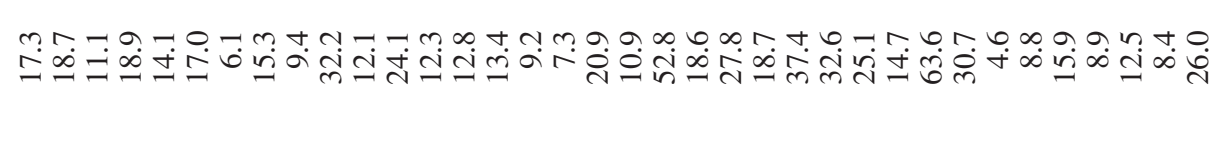 \\
\hline ]ี & $\frac{T}{2}$ & \\
\hline$\dot{\dot{\varphi}} \dot{\dot{\theta}}$ & 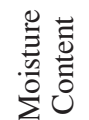 & 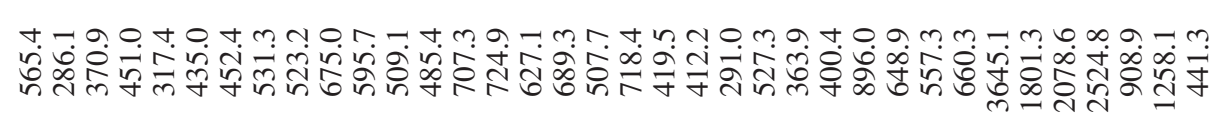 \\
\hline 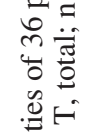 & 官 & 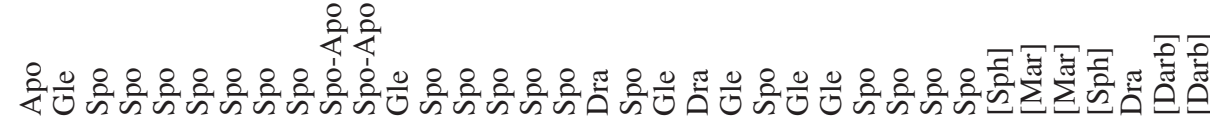 \\
\hline 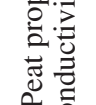 & $\ominus$ & 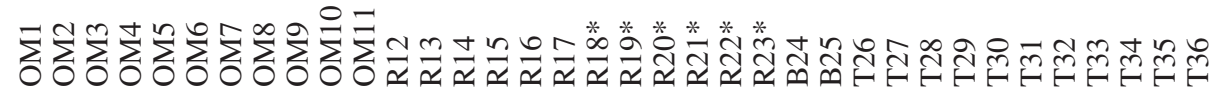 \\
\hline 希芒 & 胥 & 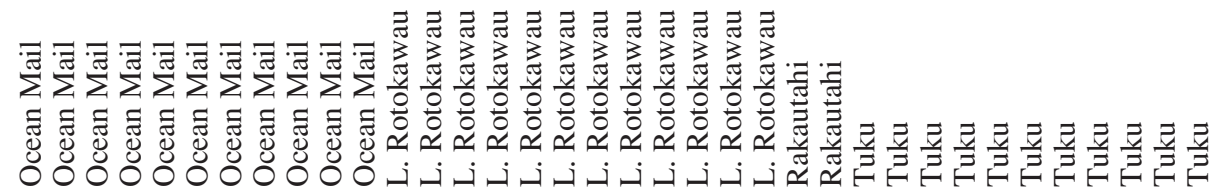 \\
\hline
\end{tabular}


Appendix 2 Plant species recorded in vegetation plots on Chatham Island. *, non-native species; ${ }^{\mathrm{t}}$, confined to Tuku forest plot T36 dominated by Dracophyllum arboreum

Taxon

Family

\section{Vascular species}

Anthoxanthum odoratum* L.

Apodasmia similis (Edgar) B.G.Briggs \& L.A.S.Johnson

Aporostylis bifolia (Hook.f.) Rupp \& Hatch

Asplenium flaccidum ${ }^{\mathrm{t}} \mathrm{G}$.Forst.

A. oblongifolium ${ }^{\mathrm{t}}$ Colenso

A. polyodon ${ }^{\mathrm{t}} \mathrm{G}$.Forst.

Baumea rubiginosa (Spreng.) Boeck.

B. tenax (Hook.f.) Blake

Blechnum novae-zelandiae T.C.Chambers \& P.A.Farrant

(swamp form "B. minus")

B. procerum (G.Forst.) Sw.

Carex chathamica Petrie

Carex sectoides (Kuk.) Edgar

Cerastium glomeratum* Thuill.

Centella uniflora (Colenso) Nannf.

Coprosma chathamica Cockayne

Coprosma propinqua var. martinii W.R.B.Oliv.

Corokia macrocarpa ${ }^{\mathrm{t}}$ Kirk

Corybas sp.

Ctenopteris heterophylla (Labill.) Tindale

Cyathea cunninghamiit Hook.f.

Cyathodes robusta Hook.f.

Dicksonia fibrosa ${ }^{\mathrm{t}}$ Colenso

D. squarrosat (G.Forst.) Sw.

Dracophyllum arboreum Cockayne

Dracophyllum scoparium Hook.f.

Drosera binata Labill.

Gentiana chathamica Cheeseman

Gleichenia dicarpa $\mathrm{R} . \mathrm{Br}$.

Ficinia nodosa (Rottb.) Goetgh. Muasya \& D.A.Simpson

Hierochloe redolens (Vahl) Roem. \& Schult.

Holcus lanatus* L.

Hydrocotyle novae-zeelandiae DC.

Hymenophyllum demissum ${ }^{\mathrm{t}}$ (G.Forst.) Sw.

H. dilatatum ${ }^{\mathrm{t}}$ (G.Forst.) Sw.

H. multifidum ${ }^{\mathrm{t}}$ (G.Forst.) Sw.

H. scabrum ${ }^{\mathrm{t}}$ A.Rich.

Hypochaeris radicata* $\mathrm{L}$.

Hypolepis distans Hook.

Isolepis distigmatosa (C.B.Clarke) Edgar

Juncus articulatus* L.

J. bufonius* L.

J. effusus* L.

J. pallidus R.Br.

J. planifolius $\mathrm{R} . \mathrm{Br}$.

Leontodon taraxacoides* (Villars) Merat

Leptinella potentillina F.Muell.

Lepidosperma australe (A.Rich.) Hook.f.

Libertia peregrinans Cockayne \& Allan

Lobelia anceps L.f.

Luzula banksiana var. acra Edgar

Myriophyllum pedunculatum subsp. novae-zelandiae Orch.

Myrsine chathamica ${ }^{\mathrm{t}}$ F.Muell.
Poaceae

Restionaceae

Orchidaceae

Aspleniaceae

Aspleniaceae

Aspleniaceae

Cyperaceae

Cyperaceae

Blechnaceae

Blechnaceae

Cyperaceae

Cyperaceae

Caryophyllaceae

Apiaceae

Rubiaceae

Rubiaceae

Escalloniaceae

Orchidaceae

Grammitidaceae

Cyatheaceae

Epacridaceae

Dicksoniaceae

Dicksoniaceae

Epacridaceae

Epacridaceae

Droseraceae

Gentianaceae

Gleicheniaceae

Cyperaceae

Poaceae

Poaceae

Apiaceae

Hymenophyllaceae

Hymenophyllaceae

Hymenophyllaceae

Hymenophyllaceae

Asteraceae

Dennstaedtiaceae

Cyperaceae

Juncaceae

Juncaceae

Juncaceae

Juncaceae

Juncaceae

Asteraceae

Asteraceae

Cyperaceae

Iridaceae

Lobeliaceae

Juncaceae

Haloragaceae

Myrsinaceae 
Appendix 2 (Continued)

Taxon

Family

M. coxii ${ }^{\mathrm{t}}$ Cockayne

Nertera depressa Banks \& Sol. ex Gaertn.

Olearia semidentata Decne ex Hook.f.

Plantago australis* Lam.

Phormium tenax J.R. \& G.Forst.

Plantago coronopus L.

Poa annua* $\mathrm{L}$.

Poa chathamica Petrie

Pratia arenaria Hook.f.

Peusdopanax chathamicus Kirk

Pteridium esculentum (Forst.f.) Cockayne

Ripogonum scandens ${ }^{\mathrm{t}}$ J.R. \& G.Forst.

Rubus fruticosus* $\mathrm{L}$.

Rumex acetosella* L.

Sagina procumbens* L.

Selliera radicans Cav.

Sporadanthus traversii (F.Muell.) F.Muell. ex Kirk

Thelymitra cyanea (Lindl.) Benth.

Trichomanes reniforme ${ }^{t}$ G.Forst.

Uncinia rupestris Raoul

Utricularia delicatula Cheesem.

Non-vascular species

Campylopus acuminatus var. kirkii (Mitt.) Frahm

Chiloscyphus semiteres (Lehm.) Lehm. \& Lindenb.

Cladia retipora (Labill.) Nyl.

Cladina leptoclada (des Abb.) D.Galloway

Dicranoloma billardieri (Brid. ex anon.) Par.

Hypnum chrysogaster C.Muell.

Kurzia compacta (Steph.) Grolle

Marchantia berteroana Lehm. \& Lindenb.

Pallavicinia lyellii (Hook.) S.Gray

Pohlia ?nutans (Hedw.) Lindb.

Ptychomnion aciculare (Brid.) Mitt.

Riccardia cochleata (Hook.f. \& Taylor) Kuntze

R. crassa (Schwaegr.) Carrington \& Pearson

Sphagnum australe Mitt.

S. falcatulum Besch.

Stereocaulon sp.
Myrsinaceae

Rubiaceae

Asteraceae

Plantaginaceae

Phormiaceae

Plantaginaceae

Poaceae

Poaceae

Lobeliaceae

Araliaceae

Dennstaedtiaceae

Ripogonaceae

Rosaceae

Polygonaceae

Caryophyllaceae

Goodeniaceae

Restionaceae

Orchidaceae

Hymenophyllaceae

Cyperaceae

Lentibulariaceae

Dicranaceae

Geocalycaceae

Cladoniaceae

Cladoniaceae

Dicranaceae

Hypnaceae

Lepidoziaceae

Marchantiaceae

Pallaviciniaceae

Bryaceae

Ptychomniaceae

Aneuraceae

Aneuraceae

Sphagnaceae

Sphagnaceae

Stereocaulaceae 